\title{
Effectiveness of State Reserve Requirements
}

\author{
R. ALTON GILBERT
}

A

$\mathrm{N}$ important decision made by each commercial bank is whether to be a member of the Federal Reserve System (FRS). National banks are required by law to be members but can withdraw from membership with little difficulty by obtaining state charters. State banks may choose whether to be members without affecting the status of their state charters.

In recent years many banks have withdrawn from the FRS, and the primary reason given is that they must hold a larger share of their assets in non-earning form as members than if they were nonmembers. ${ }^{1}$ The FRS has proposed to reduce member bank reserve requirements as a means of making membership more attractive, State bank regulators, however, might wish to counter this action in order to keep the number of banks under their supervision from declining, and might seek to do so by lowering reserve requirements for nonmember banks. For states to offset the effects of a reduction in $F$ RS reserve requirements on the attractiveness of membership, state reserve requirements would have to be effective, in the sense of influencing the cash holdings of nonmember banks or other aspects of nonmember bank behavior. Thus, effectiveness of state reserve requirements is one of the issues to consider in estimating the attractiveness of proposals for reducing member bank reserve requirements.

Effectiveness of state reserve requirements is andlyzed from three approaches. The first approach examines how close nommember banks keep their cash reserves to required cash reserves. A second approach examines the influence of state reserve requirements on the way nonmember banks report their uncollected funds. Most states do not count cash items in the process of collection (CIPC) as cash reserves; however, nonmember banks in such states can use uncollected funds to meet reserve requirements by reporting them as demand balances due from correspondents, instead of as CIPC. This second approach tests whether nonmember banks in states which do not

\footnotetext{
1Peter Rose, "Exodus: Why Banks are Leaving the Fed," The Bankers Magazine (Winter 1976), pp. 43-49.
}

count CIPC as cash reserves report more of their uncollected funds as demand balances due from correspondents than nonmember banks in other states. A third approach tests the effects of state reserve requirements on the percentages of banks which are FRS members in various states. Details of state reserve requirements are reported in a previous issue of this Review.2

\section{FIRST APBOACII}

\section{Nature of Dake Analable and Appopriate Commatsons}

Most state banking authorities compare average cash assets to required cash reserves over one-week or two-week periods to determine whether banks are meeting their reserve requirements. However, data are available in a common format across states only as

2R. Alton Gilbert and Jean M. Lovati, "Bank Reserve Requirements and Their Enforcement: A Comparison Across States," this Review (March 1978), pp. 22-32. Another approach that has been used to test the effectiveness of state reserve requirements is to estimate the relation between cash assets held by nonmember banks and reguired cash reserves. See Lawrence G. Goldberg and John T. Rose, "Do State Reserve Requirements Matter?" Journal of Bank Research (Spring 1977), pp. 31-39. That approach is not used in this paper for the following reasons. If state reserve requirements infuence cash holdings of nonmember banks, demand for correspondent balances by nonmember banks would also be a function of additional variables, which should be held constant in testing the influence of state reserve requirements on cash holdings of nonmember banks. Data on some other determinants of demand for correspondent balances, such as daily variability of deposit liabilities, are not available for nonmember banks. For evidence on the significance of deposit variability for demand for correspondent deposits, see William G. Dewald and G Bichard Dreese "Bank Behavior with Respect to Depasit Variability," Joumal of Finance (September 1970), pp. 869-79. Another reason concerns the interpretation if a positive relation is found between cask holdings and required cash reserves of nonmember banks. Such a relation might indicate that banks which hold relatively large percentages of their assets in cash do so because of relatively high reserve requirements. On the other hand, such a relation right indicate that state banking authorities keep reserve requirements relatively high in states in which nonmember banks hold relatively high percentages of their assets in cash voluntarily. In such states there would be little pressure on banking alythorities from banks to lower reserve requirements. In other states in which banks wish to hold lower cash ratios, banking authorities would be under pressure to keep reserve requirements no higher than voluntary cash holdings. 
of individual days. One source is the quarterly Report of Condition for all Federally insured banks; the other is balance sheets as of each Wednesday for nonmem. ber weekly reporting banks. Since these observations are for individual days, at quarterly or weekly intervals, observed cash holdings may be less than the required amounts without necessarily indicating that banks are violating state reserve requirements. AIternately, reserves could be above required levels as of individual days without necessarily indicating that nonmember banks voluntarily hold more reserves than required.

Another complication in drawing condusions from ratios of reserves to required reserves for effectiveness of state reserve requirements is that banks often choose to hold excess reserves. Relatively small member banks hold substantial amounts of excess re serves, although most of them would tend to hold less cash if their reserve requirements were reduced. ${ }^{3}$

These problems of interpretation are dealt with by comparing the ratio of cash reserves to required cash reserves for nonmember banks with the ratio of reserves to required reserves for member banks of comparable size, calculated for the same individual days. The nonmember ratios are calculated using state requirements, and member bank ratios using FRS requirements. Member bank reserve requirements are used here as a standard for effective reserve requirements. To indicate how this standard is applied, suppose nommember banks have ratios of cash reserves to required cash reserves which are significantly higher than such ratios for member banks of comparable size. State reserve requirements would be considered not effective, in the sense that cash holdings of nonmem. ber banks apparently would not be determined by state reserve requirements to the same extent that reserves of member banks are determined by their required reserves.

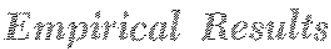

One recent quarterly Report of Condition is used to calculate ratios of cash reserves to required cash re serves for member and nommember banks of compa-

\footnotetext{
"There tend to be economies of scale in managing a bank's reserve position. For instance, Treasury bills have minimum dollar denominations, and correspondent banks generaly have minimum dollar units in which they invest excess reserves of respondent banks in the Federal funds market. Also, there are efficiencies due to specialization, since the persons who manage the reserve positions of relatively small banks generally have additional tesponsibilities. Txcess reserve ratios of relatively somall member barks indicate that the transactions and cash management costs which are necessany to reduce excess reserves are larger than the potential increases in income from investing them.
}

rable size. These calculations indicate that nonmember banks in most states hold cash reserves which are sub. stantially larger than their required cash reserves. Cash reserves several times as large as reguired cash reserves were most common among the smallest nonmember banks, with larger banks having smaller ratios. In all but two of the 38 states for which such comparisons are made, the average ratios of cash reserves to required cash reserves were significantly higher than those ratios for member banks of comparable size. Thus, based moon this infomation, state reserve requirements appear to be less effective than FRS reserve requirements. ${ }^{*}$ Details of calculations and statistical tests are presented in section I of the Appendix.

In 1976 there were 23 weekly reporting banks which were nonmembers. Two of those banks were located in states with no cash reserve requirements. Of the remaining 21 banks, 12 had average ratios of cash reserves to required cash reserves which were not significantly different from such ratios for member banks of comparable size." These 12 banks are located in seven states. Thus, results for nonmember weekly reporting banks provide evidence of effective state reserve requirements for some of the relatively large nonmember banks in several states.

There are only a few nonmember banks that are as large as weekly reporting banks. Evidence from this approach indicates that state reserve requirements are not effective for most nonmember banks in all but a few states, simce their cash holdings are so much larger than their required cash reserves.

\section{SEOND ABMOACU}

All but seven states have reserve requirements which must be satisfied completely, or in part, with cash reserves, which include vault cash and demand deposits with other domestic commercial banks. Among the 43 states with reserve requirements which must be met with cast assets, 17 allow banks to count at least some types of cash items in the process of collection (CIPC) as cast reserves. CIPC represent primarily the dollar value of checks deposited with correspondent banks for which the correspondents have not received payment.

\footnotetext{
Note that this result does not imply a comparison of the burden of reserve requinements of FRS members to the burden of state reserve requirements for nonmembers. The issue being considered is how close member and nonmember banks keep their cash reserves to their respective required cash reserves.

5 Each of the nonmember weekly reporting banks in $1976 \mathrm{had}$ total deposits greater than $\$ 180$ million.
} 
Differences among states in treatment of CIPC as reserves could have significant implications for the effective levels of state reserve requirements if nonmember banks reported all of their uncollected funds as CIPC, because uncollected funds constitute substantial proportions of required reserves for most banks. "However, many banks report part or all of their uncollected funds as demand balances due from correspondents. Some banks may follow such an accounting practice to use uncollected funds for meeting reserve requirements. To illustrate why a bank might do this, consider a nonmember bank which desires to hold an amount of vault cash plus collected demand balances with correspondents which is less than its required cash reserves. If this bank is in a state which does not count CIPC as reserves, it could increase its reserves for purposes of meeting state requirements by classifying its uncollected deposits at correspondents as demand balances due from banks, rather than as CIPC.

Regression analysis is used to test the influence of state reserve requirements on the methods nonmember banks use for classifying uncollected funds. Two hypotheses are tested: in states that have cash reserve requirements and do not count CIPC as reserves, (1) nonmember banks report less of their uncollected funds as CIPC than do other banks, and (2) the percentage of banks reporting uncollected funds as CIPC is smaller in states with higher reserve requirements and in states which enforce reserve requirements more rigorously.

The regression results support both of these hypotheses (see Appendix, section III). The percentage of nonmember banks reporting CIPC as zero is significantly higher in states that have cash reserve reguirements and do not count CIPC as cash reserves. Another measure of how nonmember banks report uncollected funds is the percentage of banks reporting CIPC less than 25 percent of their demand balances due from correspondents. With this second

\footnotetext{
BUncolected funds as a proportion of cash assets can be measured most accurately for member banks which send most of thetr checks to a Federal Reserve Bank for collection. Mem. ber banks receive credit for deposits with Reserve Banks according to a time schedule which approximates the time required sor the FRS to make collection. Uncollected funds which represent deposits at Fectera Feserve Banks for which member barks have not yet received cretit must be reported as CIPC. For group of 49 member banks which regularly deposit chedks with their Federal Reserve Bank, CIPC was bout 83 percent of their reserve balances with their Federal peserve Bank. See P. Alon Glbart, "Utilization of Federal Reserve Bank Services By Rember Banks: Inplications for

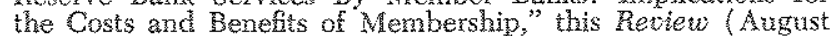
$(977), p+3$
}

measure as the dependent variable, significant independent variables are those which reflect treatment of CIPC as cash reserves, the level of state reserve requirements, and methods of monitoring reserve positions of nonmember banks.

These results have implications for the level of state reserve requirements relative to cash assets nonmember banks would desire to hold voluntarily. Cash reserve requirements of several states tend to be large enough relative to voluntary holdings of vault cash plus collected demand balances due from correspondents to induce behavior by nonmember banks which minimizes the burden of state reserve requirements. Whether nommember banks are able to fully offset the burden of state reserve requirements by reporting uncollected funds as demand balances due from correspondents cannot be determined from this analysis.

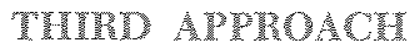

The major cost of Federal Reserve membership is reserves required of members, relative to reserves held by nonmembers. If state reserve requirements are effective, differences in requirements among states would tend to induce differences among states in the percentages of banks that choose Federal Reserve membership: the percentage of banks within a state that are members of the Federal Reserve System would tend to be higher in states with relatively high state reserve requirements and rigorous enforcement by state banking authorities.

This hypothesis is also tested using regression analysis. ${ }^{7}$ Results of those tests indicate that the percentage of banks in the Federal Reserve is not significantly higher in states with relatively high reserve requirements. Thus, by just examining the levels of state reserve requirements, such requirements do not appear to infiuence the membership choice of banks.

Two aspects of the enforcement of state reserve requirements, however, do significantly influence the choices of banks concerning FRS membership. The most important variable reflects differences among states in methods of monitoring the reserve positions of nommember banks. The most rigorous method state bank supervisors use to monitor the reserve positions of nonmember banks is frequent reports from banks on their reserve positions. The percentage of banks in

\footnotetext{
iSee the Appendix, section IV, for description of the data and staistical fests.
} 
the Fed is significantly higher in states which require nonmember banks to file frequent reports on their reserve positions than in states which use less rigorous methods to monitor compliance with reserve requirements. This result is consistent with the hypothesis that banks are more likely to choose Fed membership in states with more rigorous enforeement of reserve requirements.

The other significant aspect of state reserve requirements is enforcement of penalties on reserve deficiencies. Several states have dollar penalties which are relatively low or, according to the state banking supervisors, are seldom enforced. The percentage of banks in the Fed is significantly lower in such states than in other states which have higher dollar penalties, enforce dollar penalties on reserve deficiencies more rigorously or have various types of nondollar penalties.

These results indicate that enforcement of state reserve requirements, not the level of requirements, influences the choice of banks concerning Federal Reserve membership. One possible explanation for this finding is that the measures of enforcement requirements for reporting on reserve positions, the level of dollar penalties, and degrees to which penalties are imposed - reflect differences among states in the nature of bank supervision in general, not just enforcement of reserve requirements. Additional research would be necessary to determine whether states with relatively more rigorous enforcement of reserve requirements also have more rigorous enforcement of other banking regulations.

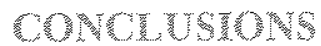

Empirical tests presented in this paper provide conflicting evidence on the effectiveness of state reserve requirements. Most nonmember banks in all but a few states hold ratios of cash reserves to required cash reserves which are significantly larger than ratios of reserves to required reserves for member banks of comparable size. These results are consistent with the view that the cash holdings by most nonmember banks are not determined by state reserve requirements, but by cash requirements for banking transactions. Under this interpretation, most nonmember banks would not tend to hold less cash if their cash reserve requirements were reduced. Thus, states could not offset Federal Reserve System (FRS) actions intended to increase the attractiveness of membership - such as lowering nember bank reserve requirements - by lowering reserve requirements for nonmember banks in response.
However, other evidence presented above calls for qualifications to this general conclusion. Several relatively large nonmember banks (total deposits of $\$ 180$ million and above) keep their cash reserves as closely tied to their required cash reserves as do member banks of comparable size. This evidence indicates that state reserve requirements are effective for some of the relatively large nonmember banks in several states.

Other evidence which is not necessarily consistent with the general conclusion on effectiveness of state reserve requirements is that on reporting of uncollected funds by nonmember banks. In states which do not count cash items in the process of collection (CIPC) as cash reserves, nonmember banks report CIPC which is a smaller percentage of their demand balances due from correspondents than do nonmember banks in other states. This evidence indicates that nonmember banks tend to use their means of reporting uncollected funds to minimize the burden of state reserve requirements.

Additional evidence which supports the conclusion that state reserve requirements are not effective concerns the influence of state reserve requirements on the percentage of banks in various states which are FRS members. The level of state reserve requirements does not significantly influence the percentage of banks which are FRS members. However, some differences among states in methods of monitoring the reserve positions of nonmember banks and enforcing reserve requirements are significantly related to differences in the percentage of banks that are FRS members.

An overall assessment of results in this analysis supports the view that in general state reserve requirements are not effective. Evidence cited above which is inconsistent with this general conclusion calls for only limited qualifications, and may raise more questions than it answers.

Only a small number of nommember banks have total deposits over $\$ 180$ million. Thus, evidence on effectiveness of state reserve requirements for several nonmember banks in that size range applies to only a small percentage of banks which would posssibly be infuenced by a reduction in FRS reserve requirements.

Evidence that nonmember banks in some states attempt to minimize the burden of state reserve requirements by the way they report uncollected funds does not indicate whether any burden remains after banks take such actions. Nonmember banks in states 
which do not count CIPC as cash reserves may be able to avoid all burderi of state reserve requirements by reporting their uncollected funds as demand balances due from correspondents.

Differences among states in methods of monitoring reserves of nonmember banks and enforcing reserve requirements may be related to differences among states in overall stringency of banking regulation. Therefore, the evidence cited above conceming variables which influence the percentages of banks which are FRS members may indicate as much about the influence of differences among states in overall bank regulation as it does about the influence of state reserve requirements on membership choice.

Thus, evidence developed in this paper indicates that the FRS could increase the attractiveness of membership by lowering member bank reserve requirements. With only a few exceptions, states could not offset the effects of such an action by lowering reserve requirements for nonmember banks.

\section{APPENDIX}

\section{Specification of Data and Empirical Results}

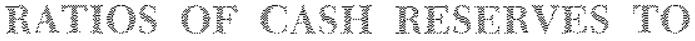

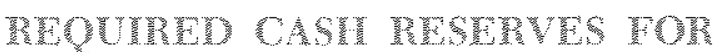

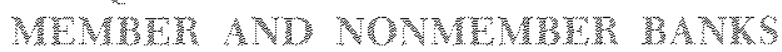 \\ Watas trom the pront of Conditon}

Ratios of cash reserves to required reserves are calculated for all nonmember banks in states that have cash reserve requirements, using data as of June $30,1976 .{ }^{1}$ The ratios are averaged for nonmember banks in each state within the following size groups in terms of total deposits:

(a) up to $\$ 10$ million,

(b) $\$ 10$ million to $\$ 50$ million,

(c) $\$ 50$ million to $\$ 100$ million, and

(d) $\$ 100$ million to $\$ 500$ million. $^{2}$

Average ratios of reserves to required reserves are presented in Table A-1. Each t-statistic (calculated for the

1 See Appendix, section II, for discussion of a possible bias in the Report of Condition data.

'In most states there are few, if any, nonmember banks with total deposits over $\$ 500$ million. The influence of bank size on the ratios of reserves to required reserves is held constant by dividing nonmember banks' in each state into these size groups. A few banks which had extreme ratios were eliminated from the analysis. The banks which were eliminated from calculations in this section were also eliminated from analysis in the following sections. Another study has drawn inferences about the effectiveness of state reserve requirements based upon reserve ratios from the Report of Condition. One limitation of the study is that no criterion was developed from determining how large reserves can be in difference between the mean ratio for nonmember banks and the mean ratio for members of comparable size) is used to test the hpothesis that reserve requirements of a state are effective. ${ }^{3}$ In each case in which the difference in mean ratios is not significantly different from zero, reserve requirements of that state are considered as signifcant in determining the cash holdings of nonmember banks as FRS reserve requirements are in determining the reserves of member banks.

Results in Table A-I indicate that nonmember banks in most states hold cash reserves which are substantially above their required cash reserves. Nonmember banks in all but two states, South Dakota and Wisconsin, had average ratios of reserves to required reserves which were significantly higher than the average reserve ratios for member banks of comparable size. Reserve requirements are relatively high in both of these states. Thus, based upon the criterion used in this section, state reserve requirements are as effective as FRS reserve requirements in only two of the 38 states examined.

relation to reguired reserves as of an individual day and yet be consistent with effective state reserve requirements. See Perry D. Quick, Appendix A, "Nonmember Bank Reserve Requirements," in "The Burden of Federal Reserve Member" ship, NOW Accounts, and the Payment of Interest on Reserves," prepared by the Staff of the Board of Governors of the Federal Reserve Systen, June 1977, pp. 71-96.

3Mean ratios of reserves to required reserves, based upon the Report of Condition for June 30,1976 , are calculated for the combined group of member banks in those states which have cash reserve requirements. This group of states includes most menber banks in the nation. 
Table A-I

RATIOS OF CASH RESERVES TO REQUIRED CASH RESERVES OF NONMEMBER BANKS

\begin{tabular}{|c|c|c|c|c|c|c|c|}
\hline State & $\begin{array}{l}\text { Size Group } \\
\text { (millions of } \\
\text { dollars) }\end{array}$ & $\begin{array}{c}\text { Percent Reserves } \\
\text { are of } \\
\text { Required Reserves }\end{array}$ & 1-sfatistic & State & $\begin{array}{l}\text { Size Group } \\
\text { (millions of } \\
\text { dollars) }\end{array}$ & $\begin{array}{c}\text { Percent Reserves } \\
\text { are of } \\
\text { Required Reserves }\end{array}$ & t-statistic ${ }^{2}$ \\
\hline \multirow[t]{2}{*}{ Alabama } & up to $\$ 10$ & $160.31 \%$ & 6.568 & North Dakota & up $10 \$ 10$ & 136.63 & 2.384 \\
\hline & $\$ 10$ to $\$ 50$ & 137.11 & 8.007 & & $\$ 10$ to $\$ 50$ & 133.11 & 6.714 \\
\hline \multirow[t]{2}{*}{ Arkansas } & up to $\$ 10$ & 209.07 & 13.958 & Ohio & up to $\$ 10$ & 265.28 & 23.989 \\
\hline & $\$ 10.70 \$ 50$ & 170.41 & 18.072 & & $\$ 1010 \$ 50$ & 210.67 & 00.000 \\
\hline \multirow[t]{4}{*}{ California } & up to $\$ 10$ & 254.89 & 22.246 & & $\$ 50$ to $\$ 100$ & 175.85 & 23.248 \\
\hline & $\$ 10$ to $\$ 50$ & 193.09 & 24.315 & Oklahoma & up to $\$ 10$ & 205.09 & 12.276 \\
\hline & $\$ 50$ to $\$ 100$ & 156.44 & 15.447 & & $\$ 10$ to $\$ 50$ & 172.73 & 19.001 \\
\hline & $\$ 10010 \$ 500$ & 138.52 & 16.745 & Oregon & $\$ 10$ to $\$ 50$ & 208.00 & 32.538 \\
\hline Connecticul & $\$ 10$ to $\$ 50$ & 249.14 & 46.290 & Pennsylvania & up to $\$ 10$ & 278.15 & 27.375 \\
\hline Georgia & $\begin{array}{l}\text { up to } \$ 10 \\
\$ 10 \text { to } \$ 50\end{array}$ & $\begin{array}{l}373.19 \\
311.54\end{array}$ & $\begin{array}{l}23.858 \\
48.760\end{array}$ & & $\begin{array}{l}\$ 10 \text { to } \$ 50 \\
\$ 50 \text { iv } \$ 100 \\
\$ 100 \text { to } \$ 500\end{array}$ & 196.38 & $\begin{array}{l}27.186 \\
10.078\end{array}$ \\
\hline \multirow[t]{3}{*}{ Indiana } & up to $\$ 10$ & 135.97 & 2.158 & 5 outh Caroling & $\$ 100$ to $\$ 500$ & 181.31 & 44.858 \\
\hline & $\$ 10$ to $\$ 50$ & 126.74 & 4.515 & 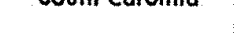 & $\$ 10$ to $\$ 50$ & 185.09 & 24.542 \\
\hline & $\$ 00 \% 10 \$ 100$ & 121.00 & & South Dakota & up to $\$ 10$ & 133.50 & 1.850 \\
\hline \multirow[t]{2}{*}{ lowa } & $\begin{array}{l}\text { up to } \$ 10 \\
\$ 10 \text { to } \$ 50\end{array}$ & $\begin{array}{l}168.42 \\
144.05\end{array}$ & $\begin{array}{l}6.662 \\
9.513\end{array}$ & & $\$ 10$ to $\$ 50$ & 131.18 & 6.167 \\
\hline & & & & Tennessee & up to $\$ 10$ & 171.08 & 7.971 \\
\hline \multirow[t]{2}{*}{ Kansas } & up to $\$ 10$ & 198.01 & $9: 821$ & & $\$ 10$ to $\$ 50$ & 151.91 & 12.646 \\
\hline & $\$ 10$ to $\$ 50$ & 168.33 & 17.578 & & $\$ 50$ to $\$ 100$ & 166.33 & 19.659 \\
\hline \multirow[t]{2}{*}{ Kentucky } & up to $\$ 10$ & 393.93 & 37.602 & Texas & up to $\$ 10$ & 180.81 & 8.870 \\
\hline & $\$ 10$ to $\$ 50$ & 366.17 & 66.537 & & $\$ 10$ to $\$ 50$ & 166.74 & 15.762 \\
\hline \multirow[t]{2}{*}{ Lovisiana } & $\$ 10$ to $\$ 50$ & 305.88 & 54.920 & & $\$ 50$ to $\$ 100$ & 155.93 & 14.250 \\
\hline & $\$ 50$ to $\$ 100$ & 217.35 & 38.815 & & $\$ 100$ to $\$ 500$ & 174.68 & 38.898 \\
\hline \multirow[t]{2}{*}{ Maryland } & up $10 \$ 10$ & $257: 78$ & 24.39 .2 & Utah & up to $\$ 10$ & 250.86 & 20.367 \\
\hline & $\$ 10$ to $\$ 50$ & 248.20 & 44.192 & & $\$ 10$ to $\$ 50$ & 157.20 & 15.127 \\
\hline \multirow[t]{2}{*}{ Massachusetts } & up to $\$ 10$ & 750.57 & 82.297 & Virginia & up to $\$ 10$ & 190.05 & 11.944 \\
\hline & $\$ 10$ to $\$ 50$ & 694.43 & 158.275 & & $\$ 10$ to $\$ 50$ & 145.62 & 11,093 \\
\hline \multirow[t]{4}{*}{ Mirhigan } & up to $\$ 10$ & 22375 & 17.321 & Washington & up to $\$ 10$ & 193.29 & 12.598 \\
\hline & $\$ 10$ to $\$ 50$ & 204.33 & 29.772 & & $\$ 10$ to $\$ 50$ & 155.98 & 14.665 \\
\hline & $\$ 50$ to $\$ 100$ & 177.70 & 23.772 & West Virginia & up to $\$ 10$ & 206.05 & 13.773 \\
\hline & $\$ 100$ to $\$ 500$ & 160.48 & 32.349 & & $\$ 10$ to $\$ 50$ & 179.97 & 22.361 \\
\hline \multirow[t]{2}{*}{ Minnesota } & up to $\$ 10$ & 222.97 & 12.884 & Wisconsin & up to $\$ 10$ & 134.81 & 1.898 \\
\hline & $\$ 10$ to $\$ 50$ & 161.08 & 12.532 & & $\$ 10$ to $\$ 50$ & 109.74 & -1.161 \\
\hline \multirow[t]{2}{*}{ Mississippi } & up to $\$ 10$ & 307.82 & 29.688 & & $\$ 50$ to $\$ 100$ & 113.53 & -1.233 \\
\hline & $\$ 10$ to $\$ 50$ & 217.57 & 32.779 & Wyomino & $\$ 10$ to $\$ 50$ & $169: 97$ & 19.538 \\
\hline \multirow[t]{3}{*}{ Missouri } & up to $\$ 10$ & 175.34 & 7.829 & -5 & & & \\
\hline & $\$ 10$ to $\$ 50$ & 142.86 & 9.474 & \multirow{5}{*}{\multicolumn{4}{|c|}{ 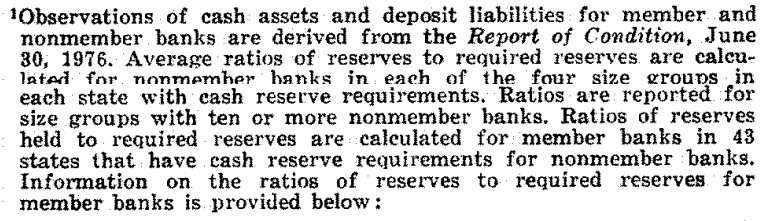 }} \\
\hline & $\$ 50$ to $\$ 100$ & 132.51 & 6.174 & & & & \\
\hline \multirow[t]{2}{*}{ Montana } & up to $\$ 10$ & 153.83 & 5.586 & & & & \\
\hline & $\$ 10$ to $\$ 50$ & 119.45 & 2.126 & & & & \\
\hline Nebroska & up to $\$ 10$ & 174.96 & 7.122 & & & & \\
\hline New Hampshire & $\begin{array}{l}\text { up to } \$ 10 \\
\$ 10 \text { to } 50\end{array}$ & $\begin{array}{l}227.72 \\
148.16\end{array}$ & $\begin{array}{l}18.810 \\
12.039\end{array}$ & $\begin{array}{c}\text { Size Group } \\
\text { (Total Deposits i } \\
\text { Millions of Dollars }\end{array}$ & $\begin{array}{c}\text { Number } \\
\text { of } \\
\text { s) } \\
\text { Banks } \\
\end{array}$ & $\begin{array}{l}\text { Mean Percent that } \\
\text { Reserves are of } \\
\text { Required Reserves } \\
\end{array}$ & $\begin{array}{l}\text { Standard } \\
\text { Deviation } \\
\text { of Ratio } \\
\end{array}$ \\
\hline New Jersey & $\begin{array}{l}\$ 10 \text { to } \$ 50 \\
\$ 100 \text { to } \$ 500\end{array}$ & $\begin{array}{l}148.78 \\
121.99\end{array}$ & $\begin{array}{r}12.083 \\
6.053\end{array}$ & \multirow{2}{*}{$\begin{array}{l}u p \text { to } \$ 10 \\
\$ 10 \text { to } \$ 50 \\
\$ 50 \text { to } \$ 100 \\
\$ 100 \text { to } \$ 500\end{array}$} & $\begin{array}{r}1082 \\
2608 \\
512\end{array}$ & $\begin{array}{l}123.18 \\
113.29 \\
116.79\end{array}$ & $\begin{array}{l}48.710 \\
28.942 \\
33.188\end{array}$ \\
\hline New Mexico : & $\$ 10$ to $\$ 50$ & 266.21 & 51.053 & & 408 & 113.25 & 33.658 \\
\hline New York & $\$ 10$ to $\$ 50$ & 134.28 & 7.198 & $\begin{array}{l}{ }^{2} \mathrm{t} \text {-statistics are ca } \\
\text { reserves to requir } \\
\text { of regerves to req }\end{array}$ & $\begin{array}{l}\text { liculated for dit } \\
\text { ed reserves of } n \\
\text { quired reserves }\end{array}$ & $\begin{array}{l}\text { ances between mea } \\
\text { nmember banks and } \\
\text { f member banks of }\end{array}$ & $\begin{array}{l}\text { ratios of } \\
\text { nean ratios } \\
\text { imilar size. }\end{array}$ \\
\hline North Carolina & up to $\$ 10$ & 205.90 & $\begin{array}{l}14.929 \\
19.862\end{array}$ & With the exceptio & on of all three : & $\begin{array}{l}\text { ze categories for } \\
\text { for South Dakata, al }\end{array}$ & $\begin{array}{l}\text { consin and } \\
\text { t-statistics }\end{array}$ \\
\hline & $\$ 10$ to $\$ 30$ & 171.30 & & are significant at & the 5 percent le & & \\
\hline
\end{tabular}




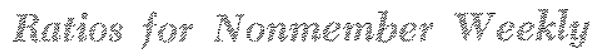

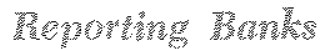

Weekly reporting banks comprise a national sample of relatively large commercial banks which report balance sheet information as of each Wednesday. In 1976, 23 weekly reporting banks were nonmembers, each with total deposits over $\$ 180$ million. Two of those banks are located in states with no eash reserve requirements. Ratios of cash reserves to required cash reserves were calculated for the remaining 21 banks as of each Wednesday in 1976 and averaged for each bank over the year (see Table A-II).

As a basis for comparison, average ratios of reserves to required reserves, under reserve requirements of the Federal Reserve, were calculated for 18 member banks in the Eighth District, with total deposits of at least $\$ 180$ million. For comparability with data for nonmembers, the measure of cash reserves for each member bank is its reserve balance at the Federal Reserve at the close of each Wednesday plus average daily vault cash during the reservo settlement week ending two weeks earlier. Aver age dally required reserves are based upon deposit liabil ities two weeks earlier. Ratios of reserves to required reserves are calculated for each member bank for each Wednesday in the period from September 15, 1976 through January 12, 1977.

Mean ratios of reserves to required reserves of the 18 member banks are used to establish an acceptance region for testing the hypothesis that the mean reserve ratio for each nonmember bank was drawn from the same distribution as that for member banks. This hypothesis is not rejected, at the 5 percent level of significance, if the mean ratio for a nonmember is in the range from 0.585 to 1.509 .

Using this criterion, the hypothesis that reserve requirements are effective is not rejected for 12 of the 21 nonmember banks, located in California, Hawaii, Michigan, New York, North Carolina, Ohio, and Pennsylvania. Thus, results in Table A-II provide evidence of effective reserve requirements in several states for some of the relatively large nonmember banks.

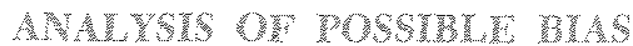

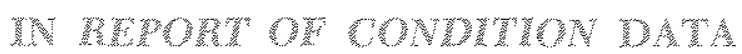

One possible problem with relying upon the Report of Condition for information on cash holdings of nonmember banks is that banks might increase their cash holdings on the known dates for the Report of Condition and reduce them immediately afterwards. Banks might behave that way if they generally hold cash reserves which are less than required reserves, since that report is disclosed to the public and made available to state banking authorities.

Determining whether cash holdings of nonmember banks from the Report of Condition are unusually high requires information from other sources for comparison. One source is the data for nonmember weekly reporting banks discussed above.

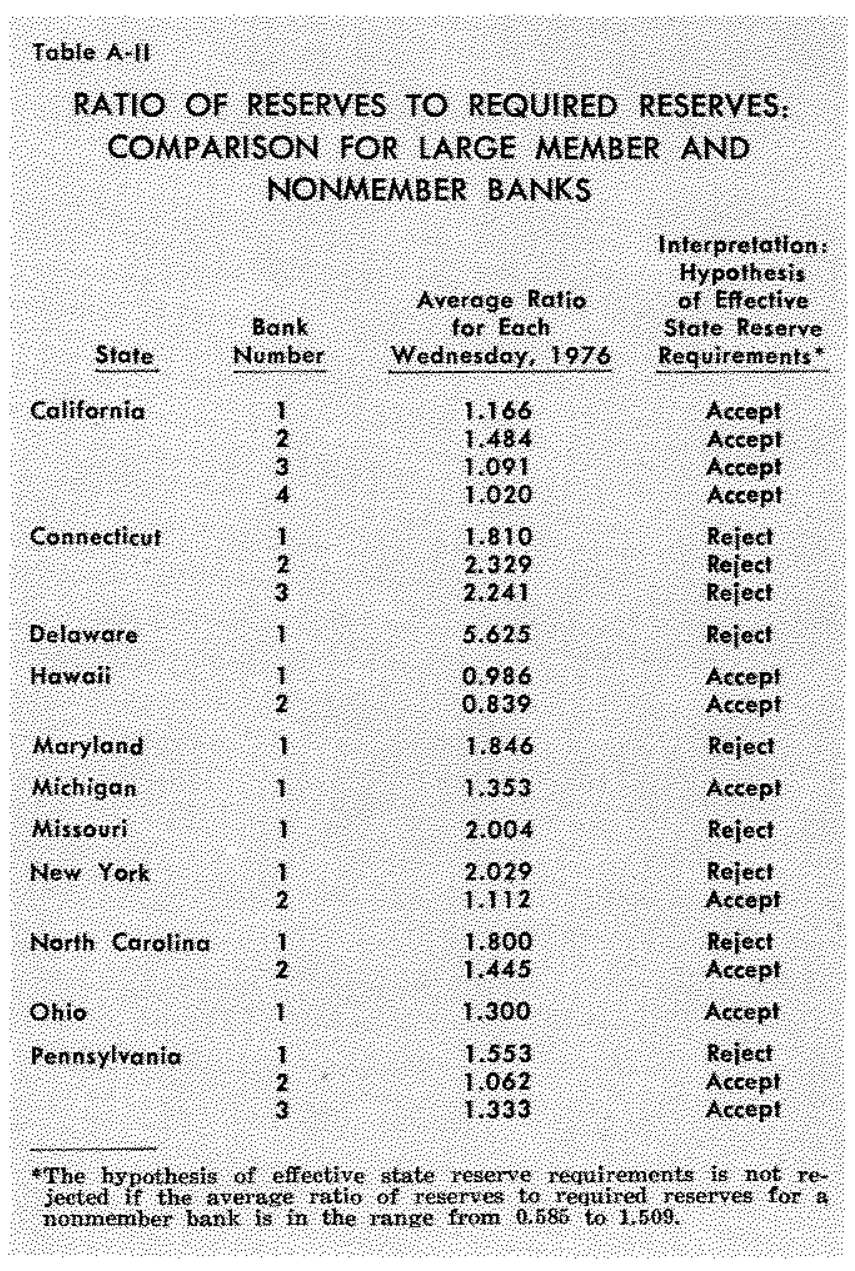

Although weekly reporting banks are larger than most nonmembers used in the calculations from the Report of Condition, they are probably part of the nonmember group which would have the greatest incentives to hold unusually high cash reserves on the Report of Condition dates. Nonmember banks in the smaller size groups in most states report cash reserves which are substantially above required cash reserves. These banks would not have incentives to hold cash reserves that much larger than their required cash reserves for just the day of the report. In contrast, the larger nonmember banks in most states tend to have lower ratios of eash reserves to required cash reserves than the small banks. Therefore, if any nonmember banks increase their cash reserves on Report of Condition dates to appear to be meeting reserve requirements, the relatively large nonmember banks would be most likely to do so.

One Wednesday in 1976 occurred on June 30, which is a Report of Condition date. For each of the 21 nonmember weekly reporting banks in states with cash reserve requirements, cash reserves reported as of June 30 are compared to the average of their cash reserves as of the four previous Wednesdays and the following four Wednesdays.

Eight of the 21 banks had higher cash reserves on June 30 than the average of both the previous and fol- 
$1010 \mathrm{~A}, \mathrm{l}$

\section{IDENTIFICATION OF INDEPENDENT VARIABLES AND SPECIICATION OF HYPOTHESES}

\begin{tabular}{|c|c|c|c|}
\hline \multirow[b]{2}{*}{ Symbor } & \multirow{2}{*}{ 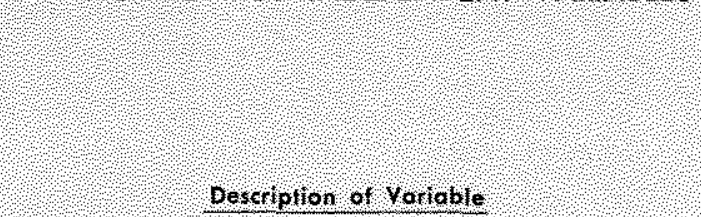 } & \multicolumn{2}{|c|}{ Direction of Infuence on Dependent Variabless } \\
\hline & & 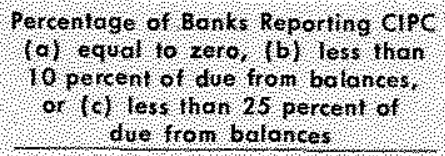 & 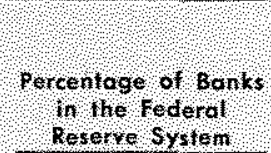 \\
\hline$M P C O$ & Percentage of zerot lember banks leporting ClPC equal & 4 & \\
\hline Mro 10 & 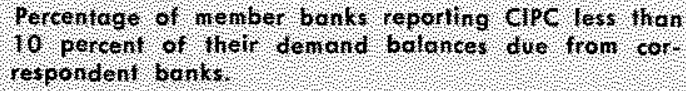 & & \\
\hline MPC 25 & 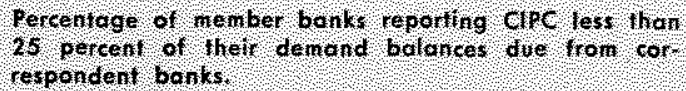 & & \\
\hline EF & 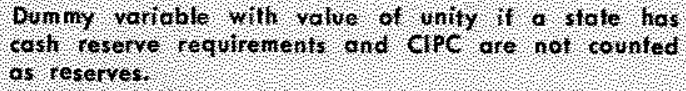 & & \\
\hline R & 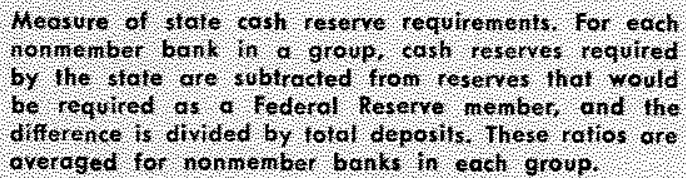 & & \\
\hline WEERLY & Yolle, of unity, it he reserge teillenent period is & 4 & $t$ \\
\hline BEWEEKLY & Yolue of unity if ile reserve setilement period is & $?$ & $?$ \\
\hline REPORT & 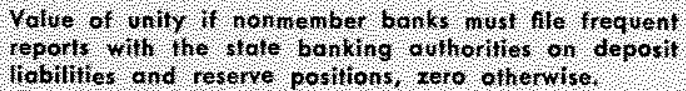 & 4 & 4 \\
\hline REC EXAM & 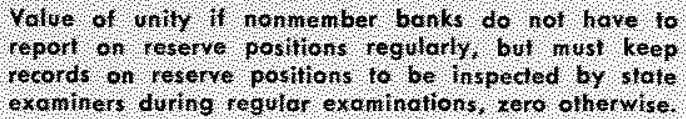 & $?$ & $?$ \\
\hline $\mathrm{REP} \mathrm{DEF}$ & 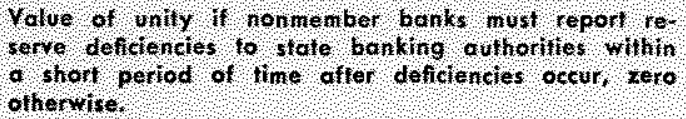 & 4 & 4 \\
\hline 10 PEN & 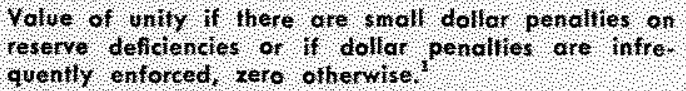 & 3 & 3 \\
\hline $11 \mathrm{PEN}$ & 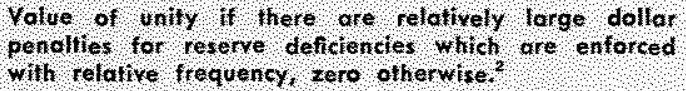 & 4 & 1 \\
\hline NE & Dunny voriable with value of unity if a stale hos & & \\
\hline Ratio 150 & 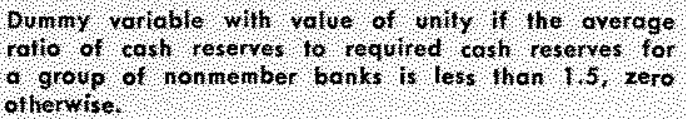 & & + \\
\hline
\end{tabular}

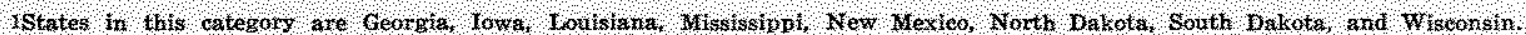

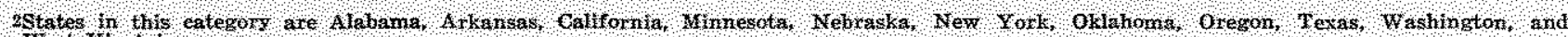
Yest vingina

lowing four weeks. However, such results may reflect largely the degree to which cash holdings of banks fuctuate on a daily basis. To illustrate such an effect, seven banks had cash reserves on Jume 30 smaller than their average in the previous and the following four weeks.

Also, some of the eight banks that had higher cash holdings on June 30 would have little incentive for holding unusually high cash reserves on the Report of Condition date. Three of them are located in states that require nonmember banks to file reports on daily reserve positions shortly after each reserve settlement period. Of the remaining five banks with especially high cash reserves on fune 30 , two had exceptionally high average ratios of reserves to required reserves over the year 1976 (average ratios of 1.85 and 2.33 ), indicating that they generally 
hold excess cash reserves. Thus, data for nonmember weekly reporting banks provide little evidence that they hold unusually high reserves on Report of Condition dates.

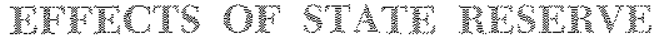

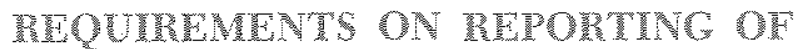 UNCOLEOMU WUNBS BY NONMEMBMT RANGS}

\section{Spectication of Voriables}

Banks in each state are divided into the size groups used in Table A-I. The following measures are used separately as dependent variables.

(a) percentage of nonmember banks which report CIPC that is equal to zero on their June 30,1976 Report of Condition,

(b) percentage of nonmembers which report CIPC that is less than ten percent of their demand balances due from correspondents, and

(c) percentage of nonmember banks which report CIPC that is less than 25 percent of their demand balances due from correspondents.

Independent variables are described below. Their hypothesized influences are summarized in Table A-III.

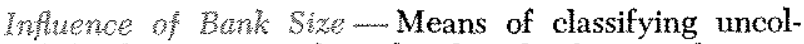
lected funds appear to be related to bank size, the percentages specified above tending to be higher for smaller banks. Influences of bank size are estimated by using dummy variables (see Table A-III for specification of those variables).

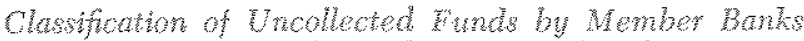
- Ratios of CIPC to demand balances due from correspondents for member banks may be systematically related to the same ratio for nonmember banks of similar size in the same state. Independent variables reflecting the practices by member banks of reporting uncollected funds are constructed in the same way as the dependent variables specified above.

Geographic and transportation factors may influence the speed with which checks are collected by both member and nonmember banks in different states. Inchuding independent variables based upon the ratios for member banks of CIPC to balances due from correspondents would account for these common influences on uncollected funds.

Another reason for including these measures for member banks is the variation among correspondent banks in methods of accounting for uncollected funds. Most of the observations in this paper are for banks with total deposits of less than $\$ 50$ million. Many member banks in that size range clear checks through correspondents instead of through the FRS. ${ }^{4}$ For these member banks, the practice of classifying uncollected funds as CIPC or balances due

4R. Alton Gilbert, "Utilization of Federal Reserve Bank Services By Member Banks: Implications for the Costs and Benefits of Membership," this Review (August 1977), pp. 2-15. from correspondents will be influenced by the accounting practices of the correspondent banks through which they and nommember banks clear checks. Member banks have no incentive to classify uncollected funds: as due from balances, since both CIPC and demand balances due from correspondents are subtracted from gross demand deposits to determine demand deposits subject to member bank reserve requirements.

Use of these measures for member banks as independent variables could bias the results. Correspondents might adjust their methods of accounting for uncollected funds to accommodate the desire of nonnembers to use uncollected funds to meet state reserve requirements. Methods of accounting for uncollected funds by member banks would reflect, to some extent, the accommodation of correspondents to nonmember bank wishes. In this case, inclusion of variables for classification of uncollected funds by member banks in the regression analysis would bias downward the estimated influence of state reserve requirements on the classification of uncollected funds by nonmembers. To allow for such bias, variables for member banks are removed in some regression equations.

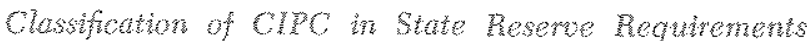
-A dummy variable is specified to reflect the incentives of nonmember banks to classify uncollected funds as demand balances due from correspondents: $\mathbf{E F F}$ has a value of unity for states that have cash reserve requirements and do not count CIPC as reserves, and has a value of zero otherwise. 5

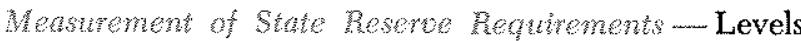
of state reserve requirements are difficult to compare. Some apply to demand deposits only; others apply to all deposits grouped together. Most states have different reserve requirements for demand and time deposits. Reserve requirements are flat percentages in some states and graduated in others. Thus, comparison of reserve requirements among states depends upon the size of banks for which comparisons are made and the composition of their deposit liabilities.

If a state allows nonmember banks to meet all of their reserve requirements with interest-earning assets, that state is considered to have no cash reserve requirements. Levels of reserve requirements are not calculated for those states. For each nonmember bank in other states, the relative level of state cash reserve requirements is measured by calculating cash reserves that would be required as a Federal Reserve member, subtracting cash reserves required as a nonmember, and dividing the difference by total deposits. This ratio, denoted as RR, is averaged for banks in each size group in the various states.

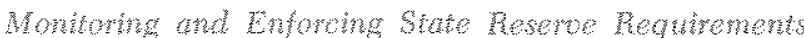
- There is substantial variation among states in procedures for monitoring the reserve positions of nonmember banks and for enforcing state reserve requirements. Dummy variables are used to reflect differences in reserve settlement periods, in methods of monitoring reserve posi-

5 Values for the levels of state cash reserve requirements and the indicators of monitoring and enforcement discussed below are set equal to zero for states that count CIPC as reserves and for those states with no cash reserve requirements. 


\section{NDEPENDENT VARIABIES}

(Itstatistics in parentheses under regression coeffitienis)

\begin{tabular}{|c|c|c|c|c|c|c|c|c|c|c|c|c|c|c|}
\hline $\begin{array}{l}\text { Equation } \\
\text { Number }\end{array}$ & Sine 10 & Size so & Size 100 & $\mathrm{MPC} 0$ & MPCI 25 & EFF & EFFRR & $\begin{array}{l}\text { EFF RR* } \\
\text { REC EXAM }\end{array}$ & $\begin{array}{l}\text { EFF RR } \\
\text { REP DEF }\end{array}$ & $\begin{array}{l}\text { EFF:RR? } \\
\text { WEERLY }\end{array}$ & Constent & $R^{2}$ & $\begin{array}{l}\text { slordord } \\
\text { Error }\end{array}$ & $\begin{array}{l}\text { Degrees } \\
\text { reodong }\end{array}$ \\
\hline toepender & varioblet & percent of & Bonmember b & the reportin & CIPC os & & & & & & & & & \\
\hline 1 & $\begin{array}{l}38.65 \\
(5.094)\end{array}$ & $(1.64,69)$ & $\begin{array}{c}0,99 \\
(-0,13)\end{array}$ & & & & & & & & $19.45,1)$ & 0.495 & 15.582 & 77 \\
\hline 2 & $8.47,4$, & $(-0.628)$ & $(-310,533)$ & $\begin{array}{l}0,87 \\
(9.834)\end{array}$ & & & & & & & 15.92, & 0,775 & 10.404 & 76 \\
\hline 3 & $(1.504)$ & $(-0.633)$ & $\begin{array}{l}3.22 \\
(-0.561)\end{array}$ & $\begin{array}{l}0.85 \\
(9.583)\end{array}$ & & $\begin{array}{l}4.01 \\
(1,734)\end{array}$ & & & & & $(10.074)$ & 0.781 & 10,270 & 75 \\
\hline 4 & $\begin{array}{l}791 \\
11331)\end{array}$ & -3.07, & $\begin{array}{r}-3.56 \\
0,619)\end{array}$ & $\begin{array}{l}0.85 \\
(9.610)\end{array}$ & & $(1,75,9)$ & $(-0,890)$ & & & & 14.96, & 0.780 & 10.284 & 74 \\
\hline 5 & $\begin{array}{l}37,77 \\
(5.091)\end{array}$ & $\begin{array}{l}8.09 \\
(1120)\end{array}$ & $\begin{array}{r}1,31, \\
-0,155)\end{array}$ & & & $\begin{array}{l}7.39 \\
(2.80)\end{array}$ & & & & & 16.49, & 0.519 & 15.216 & 76 \\
\hline 6 & $\begin{array}{l}3765 \\
(4964)\end{array}$ & $\begin{array}{l}8001 \\
(1097)\end{array}$ & $\begin{array}{r}-1,371 \\
(-0,160)\end{array}$ & & & $\begin{array}{l}7.52 \\
12.057)\end{array}$ & $(-0,104)$ & & & & $(2.5758)$ & 0.513 & 15.315 & 75 \\
\hline 7 & 3435 & $\begin{array}{l}8.276 \\
(1.279)\end{array}$ & $(-3.710$ & & & $(2,02,43)$ & & & & & $16.66)$ & 0.507 & 14.029 & 93 \\
\hline
\end{tabular}

(Dependent yarioble percent of nonemember banks reporting CAPC as, less thon $25 \%$ of demand bolances al correspondents)

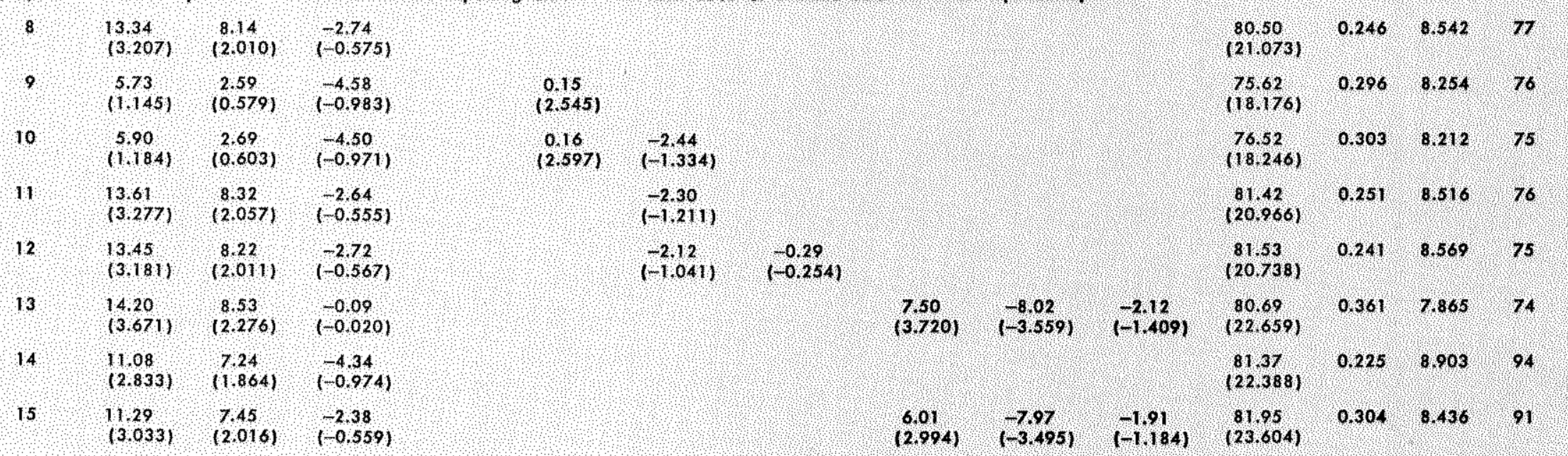


tions of nonmember banks, and in penalties for reserve deficiencies.

Intardon Thm - Variation in the level of state reserve requirements may have a stronger effect on the classification of uncollected funds by nonmember banks in those states with more strict monitoring and enforcement of state reserve requirements. Interaction terms for the level of reserve requirements and dummy variables for enforcement are included as independent variables to test this hypothesis.

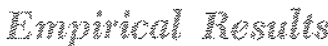

In the first seven equations in Table A-IV, the dependent variable is the percentage of nonmember banks reporting CIPC equal to zero. The percentage of member banks reporting CIPC as zero is positively related to that percentage for nonmember banks [equations (2) - (4)]. Thus, the accounting practices of member and nonmember banks appear to reflect the common influences discussed above.

The one aspect of state reserve requirements which influences the percentage of nonmember banks that report CIPC as zero is the variable for states that have cash reserve requirements and do not count CIPC as reserves (EFF), having a positive influence as hypothesized [equations (5) - (7)]. Among states with cash reserve requirements which do not count $C$ IPC as reserves, the level of reserve requirements (RR) does not add significantly to the explanation of the dependent variable [equation (6)].

However, when the percentage of member banks reporting CIPC as zero is included as an independent variable, the variable that reflects the status of CIPC in state reserve requirements (EFF) is not significant [equations (3) and (4) ]. This result is consistent with the view that both member and nonmember banks base their methods of accounting for uncollected funds upon the accounting methods of correspondent banks, and that correspondent banks adjust their accounting methods to serve the interests of nommember banks in meeting reserve requirements.

Equations (8) - (15) of Table A-IV present regression results with another dependent variable - the percentage of nonmemebr banks reporting CIPC which is less than 25 percent of their demand balances due from correspondents." Several measures of state reserve requirements are significant, if the variable reflecting the reporting of uncollected funds by member banks is eliminated from regressions. The combination of measures of reserve requirements which yields the lowest standard error Ireported in equation (13)] includes levels of state reserve requirements (RR), dummy variables reflecting differences among states in treatment of CIPC as reserves (EFF), and methods of monitoring reserve positions of nonmember banks (REC EXAM, REP DEF, and WEEKLY).7

${ }^{6}$ Effects of state reserve requirements were insignificant with the percentage of barks reporting CIPC which is less than ten percent of due from balances as the dependent variable.

TValue of the F-statistic for testing the combined influence of these three variables, compared to the explanation due to bank size variables alone, is 5.61 . With 3 degrees of freedom in the

\section{E

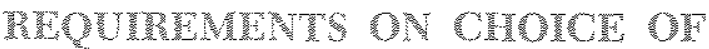

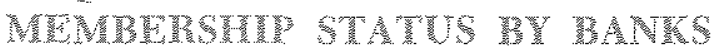

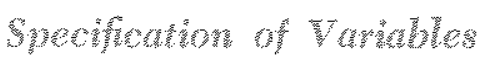

Percentage of banks that are members (as of June 1976) is the dependent variable. Membership status is strongly related to bank size; most very small banks are nonmembers and most large banks are members (see Table A-V). Effects of bank size are held constant by calculating the percentage of banks that are members in individual size groups in the various states, using the same size categories as in the previous sections. 8 Independent variables and hypotheses concerning the direction of influence of these variables on the percentage of banks that are Federal Reserve members are presented in Table A-III.

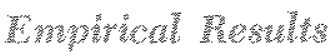

Regression results are presented in Table A.VI. One test involves two measures of reserve requirement levels as

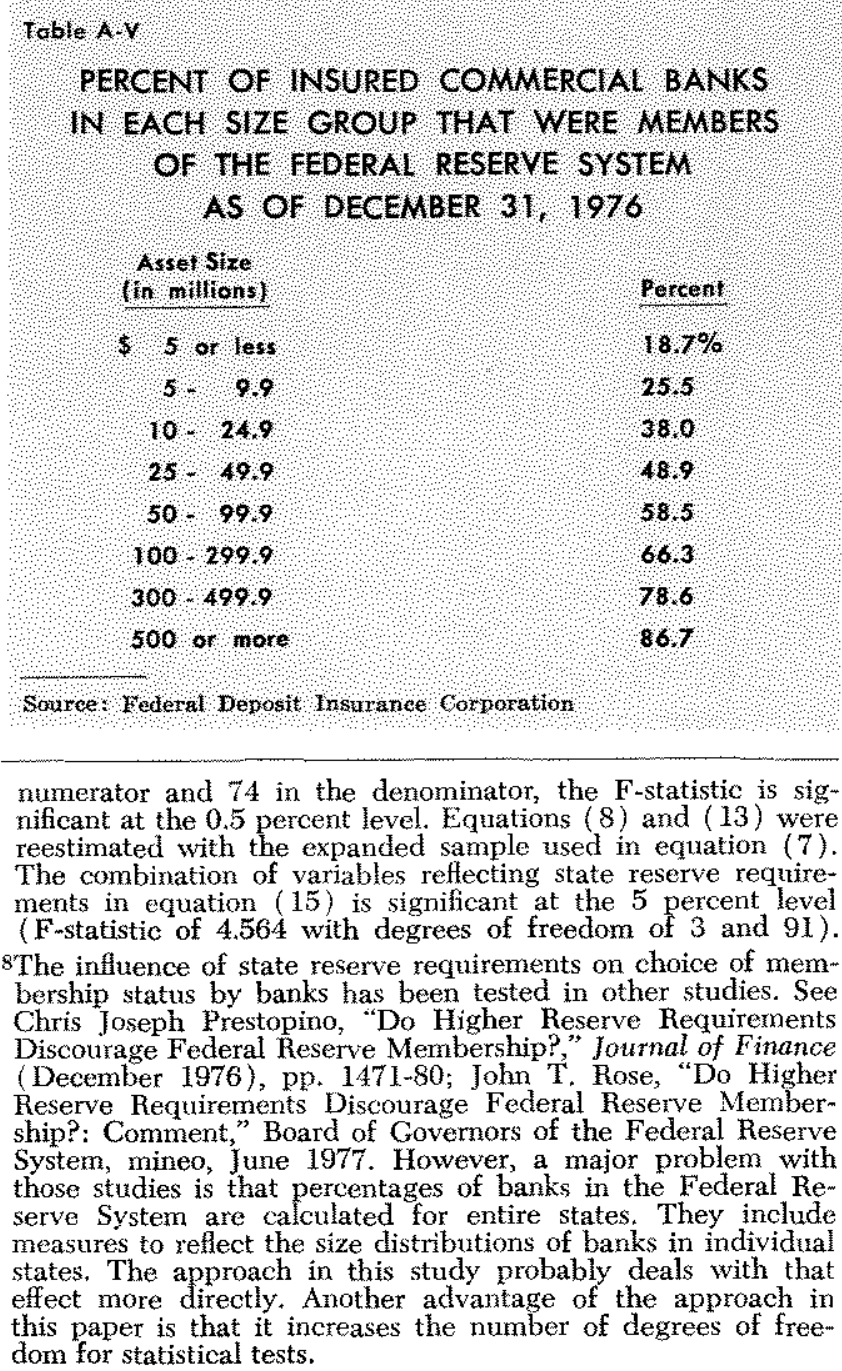

Source / Feleral Depost 1 hsurance Gorporation

Porcent

$18.7 \%$

25.5

38.0

48.9

58.5

66.3

78.6

867

numerator and 74 in the denominator, the $F$-statistic is significant at the 0.5 percent level. Equations (8) and (13) were reestimated with the expanded sample used in equation (7). The combination of variables reflecting state reserve requirements in equation (15) is significant at the 5 percent level ( $F$-statistic of 4.564 with degrees of freedom of 3 and 91 ). 8The influence of state reserve requirements on choice of membership status by banks has been tested in other studies. See Chris Joseph Brestopino, "Do Higher Reserve Requirements Discourage Federal Reserve Membership?" Journal of Finance (December 1976), pp. 1471-80; John T. Rose, "Do Higher Reserve Requirements Discourage Federal Reserve Membership?: Comment" Board of Governors of the Federal Reserve System, mineo, June 1977. However, a major problem with those studies is that percentages of banks in the Federal Reserve System are calculated for entire states. They include measures to reflect the size distributions of banks in individual states. The approach in this study probably deals with that effect more directly. Another advantage of the approach in this paper is that it increases the number of degrees of freedom for statistical tests. 


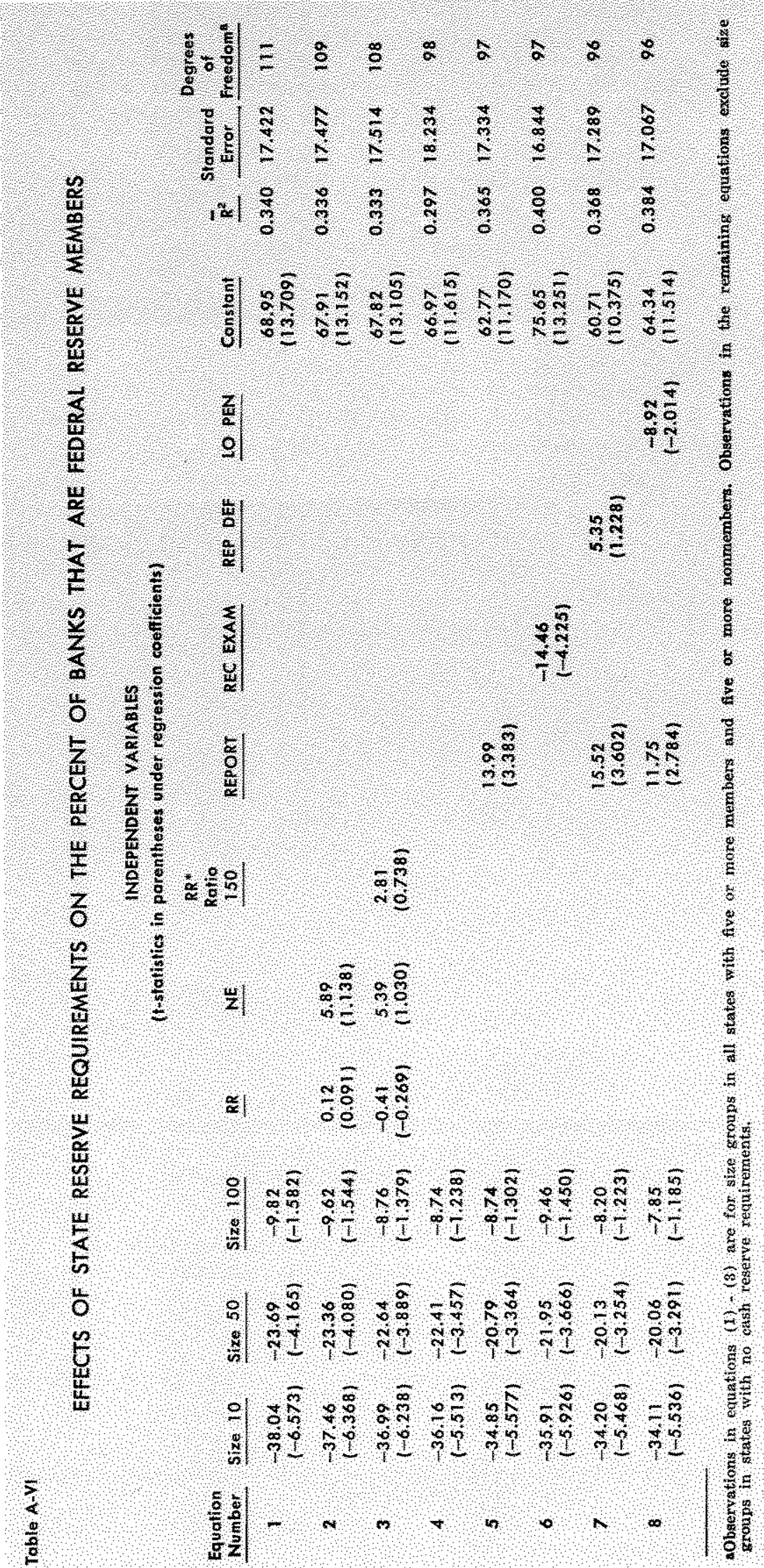

independent variables: the measure of the level of cash reserve requirements (RR) and a dummy variable for states in which there are no cash reserve requirements (NE) [equation (2)]. The regression coefficients of those variables are not significant.

The regression coefficient for the level of state reserve requirements might be insignificant due to variation among states in the amounts of cash assets that banks hold in relation to their required reserves. In some states nonmember banks hold cash assets which, on average, are several times larger than required reserves, while in other states the ratios of reserves to required reserves are close to mity. Influence of the level of state reserve requirements on the percentage of banks that are Fed members might be greatest in those states in which cash holdings are relatively close to required cash reserves.

This hypothesis is tested by adding an independent variable calculated as the level of reserve requirements (RR) multiplied by a dummy variable with a value of unity if cash reserves are less than 150 percent of required cash reserves, and zero otherwise (Ratio 150). This variable is insignificant. Therefore, if state reserve requirements influence choice of membership status, the effects will have to reflect aspects of those requirements other than just the levels of cash requirements.

The most significant aspect of state reserve requirements in influencing membership choice is the procedure for reporting reserve positions to state banking authorim ties. The percentage of banks which are nembers is significantly higher in states that require nonmember banks to file periodic reports on their reserve positions (REPORT) [equation (5) $]^{8}$

Some states monitor the reserve positions of banks by requiring them to report reserve deficiencies to the banking authorities shortly after incurring reserve deficiencies. The regression coefficient of a dummy variable which reflects this requirement (REP DEF) is not significantly different from zero [equation (7)]. With the

9 The dummy variable for states in which nonmember banks do not send reports to their state banking authorities, but keep records of reserve positions for inspection by examiners ( $R E C$ CXAM) has a negative regression coefficient which is approximately the same in absolute value as the regression coefficient for REPORT [equation (6)]. This result ind:cates that these two variables provide essentially the same information. In all but 18 of the 102 observations, either one or the other has a value of unity. Of these two variables, only REPORT is used in the other equations. 
variable for periodic reporting of reserve positions to state banking authorities (REPORT) as an independent variable, the requirement of reporting reserve deficiencies (REP DEF) does not significantly influence the nembership choice of banks.

Another variable which does significantly influence the percentage of banks in the Federal Reserve is a dummy variable for states which indicated that their dollar pen-

I0In regressions not reported in Table A-VI, the dummy variable for states with more strict enforcement of dollar penalties for reserve deficiencies (II PEN) was substituted for $L O P E N$, other variables the same as in equation $(8)$. The regression coeffeient of HI PEN was not significantly different from alties for reserve deficiencies are relatively low or seldom imposed (LO PEN). The regression coefficient for this variable is negative [equation (8)], indicating that the percentage of members is relatively low in such states. ${ }^{10}$

zero. Additional tests were conducted to determine whether differences in levels of reserve requirements among states have significant influences on the percentage of banks that are members if significant features of state policies on monitoring and enforcement are held constant. Those tests involved adding independent variables derived by multiplying the measure for levels of reserve requirements (RR) by each of the significant dummy variables for enforcement (REPORT, LO PEN). In those equations (not reported in Table A-VI) the regression coefficient for those additional independent variables were insignificant. 